\title{
Histochemistry and translational medicine
}

\author{
M.G. Manfredi Romanini \\ Dipartimento di Biologia Animale, University of Pavia, Italy
}

T his issue of the Journal is mainly devoted to a specific, crucial topic in the field of histochemical research: how in situ technologies can be exploited to study tissue samples from patients with specific diseases. The final goal is on one hand a more accurate diagnosis; on the other, the identification of specific features that can: $i$ ) be followed and compared at different time points ii) provide hints on the natural history of the disease and iii) represent surrogate end-points for targeted molecular treatments.

The European Journal of Histochemistry has always been particularly concerned with the molecular study of diseases in different tissues, and we had the privilege to publish recently several cuttingedge reports dealing with such a subject (Boniotto et al., 2003; Lanni et al., 2003; Maraldi et al., 2003; Munoz et al., 2003; Benkoel et al., 2004; Cremer et al., 2004; Rambotti et al., 2004; Trovato et al., 2004; Waltregny et al., 2004; Woodall and Graham, 2004)

In situ techniques should be considered as a part of the tremendous effort of molecular medicine in the last decades of the past century, aimed at providing a steadily improving standard for patients care, focussed as much as possible non only on clinical improvement but also on the relief from pain and disability. As it often is the case when major changes take place, modern medicine has witnessed controversies and fights, since when Jenner verified on an homeless kid the toxicity of an experimental treatment (later on defined vaccination), developed based on scanty evidence and at least questionable supporting science; so much for the current discussion on informed consent. Notably, the homeless kid became, for the sake of political correctness, the own son of the scientist in the later descriptions of the event. A similar scepticism accompanied the first usage of antibiotics (to the best of our knowledge, fungi!), or the pioneering work on organ transplantation, which originated important bioethical concerns, leading to a substantial shift in the relationship with our dead and with the intrinsic value of the human cadaver.

In these days, a lively discussion deals with the proper usage of embryonic cells. The issue should be limited to human embryonic cells: it is in our opinion reasonable that national ethical committees and funding agencies pretend that all the due respect is granted when dealing with human embryos (regardless of their origin and their final destiny). However, the overall research in such a promising field should not be indiscriminately held back, at least when non-human embryonic stem cells or stem cells deriving from adult tissues are concerned. The priority is the molecular dissection of the constrains limiting the differentiative and proliferative potential of stem cells, which will make novel cell therapy approaches feasible, valuable in different scenarios, including neurodegenerative chronic disorders or cardiovascular diseases.

We feel that cytologists and analytical cytochemists should continue their relentless effort to improve our insight about cell fate at a molecular level, with all the possible attention to the specific signals activating specific programs in diverse tissues. We should keep in mind that we are possibly the witnesses of a new technological revolution, which, as already happened in our recent past, will substantially change our perception of what human life really is.

\section{Maria Gabriella Manfredi, Romanini, Dipartimento di Biologia Animale, Piazza Botta 1027100 Pavia, Italy e-mail: MGMAR0@tin.it}

\section{References}

Benkoel L, Biagini $\mathrm{P}$, Dodero F, De Lamballerie $\mathrm{X}$, De Micco $\mathrm{P}$ Chamlian A Immunohistochemical detection of C-100 hepatitis $C$ virus antigen in formaldehyde-fixed paraffin-embedded liver tissue. 
Correlation with serum, tissue and in situ RT-PCR results. Eur $\mathrm{J}$ Histochem 2004, 48, 185-90.

Boniotto M, Pirulli D, Verga Falzacappa MV, Trevisiol C, Gerarduzzi T, Crovella $S$ Localization and expression of two human b-defensins (HBD-1 and HBD-2) in intestinal biopsies of celiac patients. Eur J Histochem 2003, 47, 389-92.

Cremer M, Zinner R, Stein S, Albiez H, Wagler B, Cremer C, Cremer T. Three dimensional analysis of histone methylation patterns in normal and tumor cell nuclei. Eur J Histochem 2004, 48 , 15-28.

Lanni C, Bottone MG, Bardoni A, Dyne K, Soldani C, Pellicciari C, Caporali R, Montecucco C Proliferation characteristics and polyploidization of cultured myofibroblasts from a patient with fibroblastic rheumatism. Eur J Histochem 2003, 47, 257-62.

Maraldi NM, Lattanzi G, Sabatelli P, Ognibene A, Columbaro M, Capanni C, Rutigliano C, Mattioli E, Squarzoni S. Immunocytochemistry of nuclear domains and Emery-Dreifuss muscular dystrophy pathophysiology. Eur J Histochem 2003, 47 , 3-16.

Munoz E, Gomez F, Paz JI, Casado I, Silva JM, Corcuera MT, Alonso MJ . Ki-67 immunolabeling in pre-malignant lesions and carcinoma of the prostate. Histological correlation and prognostic evaluation. Eur J Histochem 2003, 47 , 123-8.

Rambotti MG, Altissimi G, Spreca A Enzyme-ultracytochemical study of adenylate and guanylate cyclases in normal and pathologic human nasal mucosa. Eur J Histochem 2004, 48 , 299-308.

Trovato M, Vitarelli E, Grosso M, Alesci S, Benvenga S, Trimarchi F, Barresi G Immunohistochemical expression of $\mathrm{HGF}, \mathrm{c}-\mathrm{MET}$ and transcription factor STAT3 in colorectal tumors. Eur $\mathrm{J}$ Histochem 2004, 48 , 291-7.

Waltregny D, North B, Van Mellaert F, de Leval J, Verdin E, Castronovo $V$. Screening of histone deacetylases (HDAC) expression in human prostate cancer reveals distinct class I HDAC profiles between epithelial and stromal cells. Eur J Histochem 2004, 48, 273-90

Woodall, C.J. and Graham, D.I. Evidence for neuronal localisation of enteroviral sequences in motor neurone disease/amyotrophic lateral sclerosis by in situ hybridization. Eur J Histochem 2004, 48 , 129-34. 